\title{
Towards Religious Understanding: An Assessment of the Ambivalence Roles of Religious Leaders in Christian-Muslim Relations in Nigeria
}

\author{
Rapheal Ojo Joseph ${ }^{1}$ \\ ${ }^{1}$ Department of Religion and African Culture, Adekunle Ajasin University, Akungba-Akoko, Ondo State, Nigeria.
}

\begin{abstract}
The world today is becoming more violent than ever before. Sometimes, the violence can be political, ethnic, economic and or religious. In most cases, distinguishing the main cause of such violence from other causes might be difficult. The factors could be a combination of two issues viz: ethnoreligious conflicts or politico-religious conflicts. The religious experience in Nigeria today, as a multi-religious society so far has proven contrary to the general belief and the widespread expectation of people about religion as an institution that promotes social integration. Christian-Muslim relations in Nigeria today (though being the dominant religions in Nigeria) is standing on shaky ground. The relationship is highly characterized by mutual suspicion, mistrust and distrust. In understanding this characterized reality in their interactions, this work interrogated the ambivalence roles played by religious leaders in Nigeria. And in doing this, the ethnographic research method was adopted. As part of its findings, it was discovered that there is a high level of intolerance among Christians and Muslims in Nigeria occasioned by unguarded utterances and abuse of freedom of speech by many uncensored religious leaders. Thus, setting the stage for avoidable and constant religious confrontations among the adherents of the two religious communities in Nigeria. The study recommends that peaceful co-existence can be possible if the government is responsible and responsive enough to address the basic needs of her masses which would reduce largely the manipulation of religion by clerics for personal gain. Furthermore, the place of meaningful dialogue should be embraced by religious leaders across different religious divides.
\end{abstract}

Keywords: Christian-Muslim Relations, Dialogue, Peaceful Co-existence, Religious leaders, Religious Understanding

(C) 2021 The Author(s). Published and Maintained by Noyam Publishers.

This is an open access article under the CCBY license (http://creativecommons.org/licenses/by/4.0/).

\section{INTRODUCTION}

Globally, no nation can experience any meaningful development in an atmosphere that is devoid of peace, for it is the basis for every societal progress. It has been posited that; "There is no peace among nations and within nations unless there is peace among religions". ${ }^{1}$ This therefore underscores the view that the overall peace of every state is a function of the religious atmosphere in such a society.

The world today is more violent than ever before. Sometimes, the violence can be political, ethnic, economic and or religious. In most cases, to distinguish the main cause of such violence from other causes might be difficult. The factors could be a combination of two factors viz: ethno-religious conflicts or politico-religious conflicts. The religious experience in Nigeria today, as a multi-religious society so far has proven contrary to the general belief and the widespread expectation of people about religion as an institution that promotes social integration. Christian-Muslim relation in Nigeria today (these two religions are seen as the dominant religions) and even in the world at large is quite on shaky ground. The relationship is highly characterized by mutual suspicion, mistrust and distrust. One fundamental truth is that, there is a high level of intolerance, thus, setting the stage for religious conflicts among the adherents of the

Je'adayibe Dogara Gwamna, Religion and Politics in Nigeria, (Bukuru: ACTS Bookshop, 2010), 167. 
two religious communities in Nigeria, and other parts of the world.

Evidences abound especially in the last three decades in the Nigerian experience to support the above position. One hardly needs to do more than read the headlines to ask, what has become of Islam and Christianity's response to the issue of an interfaith enterprise? Nearly three decades have passed since the interfaith dialogue between Christianity and Islam got underway. Series of seminars, publications, symposia, among others have also been carried out with the bid to bringing to the barest minimum the constant religious log-jam and to promote religious understanding among the adherents of the two major world religions. This effort has always proved abortive as the results have often shown the contrary in the Nigerian experience especially at the dawn of 1980s. It is no doubt that many have had the reason to question the place of religion in Nigeria as it has succeeded in playing a dual role both in promoting social integration and breeding internal cleavages. This frequently results in religious confrontation among the adherents of the two religions. In line with the above position, Omoregbe observes that;

Religion, to a greater extent has aided social progress, educational development, interpersonal and international cooperation as well as mutual understanding among people. Looking at the other side of it, religion has also been the underlying force behind conflicts, civil as well as international wars, social stagnation or even retrogression, oppression, discrimination, e.t.c. Hence, religion is a double-edge sword which is capable of cutting either ways with serious consequences. ${ }^{2}$

There is no doubt that the place of religious leaders in promoting religious understanding, peace and tolerance cum respect and on the other hand provoking religious violence cannot be underestimated. Religion, as a double-edged sword, cannot be far from those that are in charge of it. The religious atmosphere in most cases can be determined by the religious leaders. Often time, the conflicting truth claims of Christianity and Islam have provoked ill will. They have carried the burden of theological competition and in most cases willed political, economic, social, and even other factors under the cover of religion. The constant religious confrontations in Nigeria suggest that there is still the seed of intolerance growing rapidly among Christians and Muslims whose leaders, when given proper examination, are not far from such religious manipulation.

It is against this backdrop that this work seeks to look at the ambivalence role of religious leaders in ChristianMuslim relations in Nigeria, as being capable of promoting religious understanding or breeding religious intolerance on the ground of religious propagation among adherents of the two faiths. Also, the work seeks to consider the effects of some unguarded utterances of these religious leaders. As well, to also proffer suggestions to the problem of religious intolerance which in most times have resulted in stark violent situations and religious confrontations among the adherents of the two religions in Nigeria. Thus, given rise to gruesome killings and wanton destruction of lives and property.

\section{Religious Leaders and Peace in Nigeria}

In the Oxford Advanced Learner's Dictionary, a leader is defined as a "person or thing that leads." 3 By this definition, one can describe a "leader" as an "opinion leader" or an "arbiter". In the religious context, they can be likened to an Imam, Reverend, Bishop, Pastor, preachers of any religion, a religious teacher of any form, and religious journalist. From the above definition, one also appreciates the importance of a leader in any given organization as the person who plans and determines the thinking and action of his followers, thus, explaining why leaders are credited or held responsible for the considerable deeds of their followers. This therefore explains the importance of leadership in every given society or organization. Even in a religious setting, this also applies because "leadership encompasses the totality of the human capacity that is displayed or can be put into driving a process at various levels in society for purposes of providing necessary convincing guidance to the followership." ${ }^{4}$ This by implication is suggestive of the fact that there is a great influence of the followers through the lifestyle or action of anyone or those that occupy the leadership position.

The activities of religious leaders across the world and Nigeria in particular today has on the one hand brought about peaceful co-existence and meaningful progress, while on the other hand, it has bred contempt, bigotry and tensed religious atmosphere, thus, snowballing into wanton destruction of lives and property. Fundamentally, it is believed that a careful study of the relationship between Christianity and Islam shows that, instead of using the areas of common interest between them to foster peaceful co-existence and better understanding, the leadership of the two religions; particularly the intellectuals or elites use a considerable amount of their efforts (including their resources) in terms of literature and sermons to incite or create hatred and enmity among the followers. ${ }^{5}$ Many books have been written not to

Joseph I. Omoregbe, Comparative Religion: Christianity and other World Religions in Dialogue, (Lagos: JOJA Press Ltd, 1991$)$, 1.

Albert S. Hornby, Oxford Advanced Learner's Dictionary of Current English, Eight Edition, Oxford New York: Oxford University Press, 2010.

4 James Igbabee Jonathan Ukpe, and Terungwa Gideon Tsendzuul, "Leadership and the Challenge of Development in Nigeria", Religions: Journal of the Nigerian Association for the Study of Religions, Vol.28 (1), January, 2018, 93.

5 Abdulrafii Oyewumi Omotosho, "Religious Violence in Nigeria - The Causes and Solutions: An Islamic Perspective", Swedish Missiological Theme, 2003, 20-21. 
bring about reconciliation and understanding but in order to present "ugly side" of the other faith, even if this so-called "ugly side" may even have been deliberately falsified. Cases in point are the works of - Moshay: "Who is this Allah" and "Anatomy of the Qur'an" on one hand, and on the other hand; "Crucifixion or Cruci-Fiction?" by Deedat. ${ }^{8}$ These works are complete examples of the casting of aspersions on what other people hold in high esteem and relegation of esteemed values and belief systems of a particular religion. Going through the various pages of these sampled published works can easily steer up nagging reactions among the differing adherents. Thus, widening the existing vacuum created by religious intolerance among the people.

The scholars, though knowing quite well that only religious respect/acceptability and the spirit of giving and take can bring about peaceful co-existence, refuse to recognize and accept the right of other faiths to exist in the first place, and even less of giving other rights that make existence meaningful. Both Christian and Muslim leaders are actively involved in campaigns of hatred against each other. This is manifested in various forms including incitement, direct or indirect distortion of facts about each other's beliefs and casting of aspersion on others (through the power of technology or media) that is often seen as a battle between "us" and "them."

From the Christian point of view, a religious leader must be seen as someone who possesses some qualities/ traits which will make such a person serve as a good example for others. In Paul's exhortation to Timothy, he listed some of those traits that are apposite for a would-be leader. He avers that:

This is a true saying, if a man desires the office of a bishop, he desireth a good work. A bishop then must be blameless, the husband of one wife, vigilant, sober, of good behaviour, given to hospitality, apt to teach; not given to wine, no striker, not greedy of filthy lucre; but patient, not a brawler, not covetous. One that ruleth well his own house, having his children in subjection with all gravity; (for if a man knows not how to rule his own house, how shall he take care of the church of God?) ... - I Timothy 3:1-7, (New International Version).

On the other hand, Islam also attaches importance to the position of leadership to the extent that no matter how small the number of Muslims in any given situation may be, be it on a journey or a gathering, a leader must be appointed. He must be the best among them in terms of spiritual disposition and character. While he is charged with good and responsible leadership, he is also assured of absolute loyalty for as long as he is within his limit. ${ }^{9}$ Therefore, religious leadership, as pointed out by Lindt ${ }^{10}$ in Encyclopaedia of Religion and quoted by Ojo can be understood as "the process by which leaders induce followers to act for certain transcendental goals that embody the values, motivations, and aspirations of both leaders and followers." 11

The above explanation shows the extent to which a leader is responsible for what goes on in his/her organization. The leadership of the two religions in Nigeria that are known for often engaging in a war of attrition cannot exonerate themselves from the present situation between their followers. This is because, whatever idea or impression is held by the followers of each religion today, depends on the kind of information that has been passed down to them either overtly or covertly by their leaders.

As a matter of fact, religion is one hard subject to approach objectively. By its nature, it dwells and thrives on emotion. Moreover, where emotion holds sway, reason is held captive. Thus, a religious argument is like the man in the anecdote. It goes around in circles, endless, inconclusive, and frustrating. According to Max, religion is the "opium of the people," 12 because it rules the heart. The gradual ascendancy of religion from the opium level to a more lethal pedestal, especially in Nigeria today is quite alarming and dreadful. Some religious leaders have been fingered to have poisoned the minds of their followers (since they have a strong influence on their minds), thus, turning little misunderstanding that ought to be settled or resolved amicably into sacred battles.

Essentially, fact states that religion is primarily a personal affair. Some may argue that religion is a communal affair. However, one would assert that it is only in religious extremism that domination, discrimination, intolerance, threat, subjugation and persecution is placed. Nonetheless, one would want to allude to the fact that the "ethics" of Christianity and Islam demand love, peace, justice, and tolerance of other people and religions. In the quest for personal gains, political interest among others, individual religious leaders and a handful of politicians exploit the underprivileged masses. In effect, the ruling elite deploy religious sentiments to polarize the people and create unnecessary and unhealthy tension.

\footnotetext{
G.J.O. Moshay, Who is this Allah? (Ontario: Chick Publications, 2010).

G.J.O. Moshay, Anatomy of the Qur'an, (Ontario: Chick Publications, 2007).

Ahmed Deedat, Crucifixion or Cruci-Fiction? (New York: Golden Empire Publications, 2011)..

Abdulrafii Oyewumi Omotosho, "Religious Violence in Nigeria - the Causes and Solutions: An Islamic Perspective," in Swedish Missiological Theme, 2003, $15-31$.

10 Gillian Lindt, "Leadership", in Encyclopaedia of Religion, Vol.8. $2^{\text {nd }}$ edition, Jones, Lindsay (ed.) (Detroit: Thomas Gale, 2005$)$, 5383.

11 James Olubukola Ojo, "Exegetical Study of Joshua 1:5-9 and the Need for Credible Leadership in African Christianity", in SamsonA. Fatokun, et al, (eds.) African Christianity in Local and Global Context, (Ibadan: Department of Religious Studies, University of Ibadan, 2019 ), 329.

12 Martin Holborn, and Michael Haralambos, Sociology: Themes and Perspectives, $7^{\text {th }}$ Edition, (London: Harper Collins Publishers Limited, 2008$), 399$.
} 
Taking a look at the Christian Crusaders at the beginning, one might be tempted to ask this question; "Can this act of cruelty be found in the teachings of Jesus Christ?" In the view of this doctrinal basis, the activities of the early Christian Crusaders were completely seen as an aberration from the original standard of peace that Jesus Christ represented and preached. Molloy therefore reiterates that; "the crusaders did ideological damage against Christianity by projecting it as killing others for religious reasons, something quite foreign to the commandment of Jesus." ${ }^{13}$ As earlier pointed out, some of these religious leaders have greatly influenced the minds of their followers, some to the positive side, while others to the negative side.

Going by some of the activities of the onetime Christian Association of Nigeria (CAN) Chairman leader -John Cardinal Olorunfemi Onaiyekan, one will see that he has taken series of steps in pursuance of religious understanding and peaceful co-existence in Nigeria. He has been an advocate of peaceful co-existence and seeing to it that what persists today as a Nigerian nation conforms to the desires of the founding fathers: Ahmadu Bello, Tafawa Balewa, Obafemi Awolowo, Nnamdi Azikwe, Herbert Macaulay, among others who passionately pursued a united nation bound together in love, unity and progress.

While addressing the issue of religious conflict with particular reference to some of the roles religious leaders are expected to play in enhancing a peaceful atmosphere, Onaiyekan, in his public lecture titled "Dividends of Religion in Nigeria," posits that;

\begin{abstract}
... When religion is dragged into conflicts that have other causes, it has the negative and unfortunate consequence that the real force and positive power of religion to bring about peace and reconciliation are compromised, jeopardized and subverted. The result is that religious leaders become not only part of the problem, but may even find themselves cast in the figure of warlords. I believe this requires careful attention on the part of all concerned beginning with religious leaders. They ought to be constantly aware they may be drafted into battles that are not God's own... Above all, religious leaders should indeed be leaders in this regard. ${ }^{14}$
\end{abstract}

The content of Onaiyekan's position here shows the overwhelming picture of every religious leader in enhancing a peaceful co-existence which he has painted and the magnitude of their influence especially when it comes to the issue of religious crisis. Since the position of leadership is a sensitive one, it therefore becomes imperative for religious leaders to see with every sense of caution how they can influence positively and never to be used as an instrument of promoting rancour or religious crisis in the society. One important thing that must be noted is the fact that a proper understanding of other people's faith must be achieved in order to respect and appreciate them for who they are and what they believe in. This therefore should start with the leaders. As Akinseye has rightly observed, in religious interaction, understanding is very important. He believes that; "when the different interacting religious groups fail to appreciate each other's merit and contribution because they do not possess the knowledge of the other people's point of view, the result will be faulty judgement and erroneous conclusion". ${ }^{15}$

Rev. Fr. Matthew Hassan Kukah is another prominent figure in the discourse on Christian-Muslim relations in Nigeria. One of his prominent works that has been able to open the minds of many to some of the issues that surround religious unrest in the Nigerian experience is titled: Religion, Politics and Power in Northern Nigeria. At the funeral mass of the December $25^{\text {th }}, 2011$ Boko Haram bomb blast at a Catholic Church in Madalla, Niger State, Nigeria, he strongly maintained that religious leaders across the faiths must stand up and face the challenge of the times by offering "a leadership that focuses on service to humanity"16. He painfully laid bare his mind that;

These are troubled times for our country; I say so because amidst this confusing debris of hate, anger and frustration, we have had some very interesting dimensions. "As Nigerians, Christians and Muslims, we must stand together to ensure that our resources are well utilised for the common good. "These are difficult times but they are also times of promise; our country has turned its back on all forms of dictatorships. "Our hands are on the plough and we are resolutely committed to democracy. ${ }^{17}$

James Wuye and Mohammed Ashafa, co-founders and national coordinators of the Muslim-Christian Dialogue Forum of Kaduna in 1995, are two men with deep roots in the opposing communities, both of whom have turned away from violence and militancy and instead embraced nonviolence, reconciliation, and the advocacy of peaceful relations between their communities. Apparently, once they were bitter rivals, but now they consider themselves brothers. As a matter of fact, they each tried to have the other killed in the past. Today, they are living proofs that people can change,

13 Michael Molloy, Experiencing the World's Religions, London: Mayfield, 2002), 6.

14 John Olorunfemi Onaiyekan, "Dividend of Religion in Nigeria", A Public Lecture Delivered at the University of Ilorin, Ilorin on $12^{\text {th }}$ May, $2010,39-40$.

15 F.A. Akinseye, "Religion and Violence: A Christian Discourse," in RaphaelA. Akanmidu, (ed.) et. al. Religion and Democracy in the $21^{\text {st }}$ Century, (National Association for the Study of Religions (NASR), 2010), 153.

16 Matthew Kukah, "Nigeria: Do not be Afraid, Bishop Kukah Appeals", Vanguard (Lagos), 16 January, 2012. (http://allafrica.com/stories/201201161505.html. Accessed on $12^{\text {th }}$ June, 2018.

17 Kukah, "Nigeria: Do not be Afraid, Bishop Kukah Appeals" 
and that the urge for revenge can be replaced by an urge to foster reconciliation and peaceful coexistence. At the point when they came to realise the need for them to embrace harmony and promote love, respect and acceptability among the two religious communities, they soberly reflected upon their past dealings and lamented that:

We both, in the past, had been involved in a war of words through various publications . . . In these papers we expressed radical, provocative ideas from the stand points of our religions, on which we would refuse to negotiate for any reason. These uncompromising attitudes, in the past, had resulted in a tense atmosphere that did not allow room for dialogue or for any form of interaction between us. Everyone was trying to outwit the other. To the Pastor, the goal was total evangelization of the country, while for the Imam it was total Islamization. These were our positions before that fateful meeting and introduction. ${ }^{18}$

It is quite perturbing that the seed of religious intolerance which had been silently sown as far back as the period of colonialism in Nigeria is now been watered by religious leaders who are in most cases unconsciously ignorant of the aftermath effects of their actions. Thus, widening the gulf of religious intolerance among the two religious communities.

\section{Religious Incitement (Polemics) and the Nigerian Peace}

Taking into consideration comments of some prominent religious leaders (both Christians and Muslims) in Nigeria, one will definitely see the concept of consolidation and expansionism as part of their major worldviews. Christian-Muslim polemics have been a major source of the hatred, fear and suspicion that exist between Muslims and Christians. There are unguarded utterances by some Christians in the south in particular, in the works of the Jehovah Witnesses, some other Pentecostal preachers and various Aladura or African Independent Churches preachers, who spare no blows in attacking and ridiculing the teachings of Islam. Muslims on the other hand, both in open $W a$ 'azi - sermon and writings, also find the opportunity to ridicule Christian beliefs. On the part of the Muslims, these religious polemics characterize the northern parts of the Nigerian society. This is also the situation in other parts of the world which is not only peculiar to Nigeria.

One will notice the worldview of an average Muslim as it re-echoes itself in the comment of a renowned Islamic leader in Nigeria and also the only Nigerian recipient of the King Faisal Laureate Award, the Muslim equivalent of the Nobel Prize - Abubukar Gumi. Records show that Gumi had repeatedly said that; "there will be no peace in Nigeria unless everyone becomes a Muslim." 19 Part of his comment was that "Nigeria will divide into two if the presidency is not in Muslim hands. ${ }^{20}$ From the political platform, Gumi will prefer a political system that is rooted in Islam. According to him, "Muslims and Christians should have their own parties. In any mixed party, Muslims would not allow a Christian to serve as leader." 21

On another occasion, a Christian leader, a renowned Catholic Cardinal Reverend in Lagos - Olubunmi Okogie, seeing the constant religious mayhem been meted on some Christians in the northern part of Nigeria reacted thus; "we just want to keep Nigeria going just because of peace, but if anybody tries any nonsense this time, I don't care, I will burn the nation because it is going to be a religious war and nobody will dare stop anybody, no gun will stop it." ${ }^{22}$ The above position of this Christian leader, to an average mind, might be seen as a threat which was probably uttered out of frustration and annoyance. But, to some Christian fundamentalists who will not be ready any more to toe the path of silence in the face of constant confrontations, it could be taken as a sign of unwillingness to "turn the other cheek", just as there appears to be an unrelenting effort on the part of the person who is 'slapping' to stop. It therefore suffices to re-echo that; religious leaders hold great sway on the people. They are been emulated by members without necessarily questioning their actions or authority as they are often considered as "God's servants" who represent God before his people. Sensitive statements, an example of which have pointed out above are often taken dogmatically by faithful followers of these religious leaders without any recourse to reasons that gave rise to them.

The place of the religious leaders and intellectuals in causing a violent religious atmosphere through their preaching, method of proselytization, unwarranted polemics, and their publications cannot be underestimated. According to Gwamna; "Some religious leaders control the minds of their adherents who are often ignorant and needy, exploiting them for selfish advantage. The "God" preached by some religious leaders seems not to be the God of justice and love, but an "intolerant God" who fosters hatred and division" "23. This does not suggest that the central object of worship 18 Emmanuel Innocent Eteng, "Imam Ashafa and Pastor James Wuye: From Enemies to Friends Building Peace"

(https://crcc.usc.edu/imam-ashafa-and-pastot-james-wuye-from-enemies-to-friends-building-peace), May 12, 2020. Accessed on 12 August, 2020.

19 Jan Hendrik. Boer, Studies in Christian-Muslim Relations - Vol.2, Muslims: Why the Violence? In Nigeria's Decades of Blood, 1980-2002, Vol.2, (Jos: Honey City Press, 2004), 141.

20 Boer, Studies in Christian-Muslim Relations, 141.

21 Boer, Studies in Christian-Muslim Relations. 142.

22 Efe Monday Ehioghae, "Religion and Violence in Contemporary Nigerian Society: A Proposal for Peaceful Co-Existence," in Rapheal A. Akanmidu, (ed.) Thoughts in the Humanity, (Ilorin: Decency Printers \& Stationary Ltd., 2011), 363.

23 Je'adayibe Dogara Gwamna, "Ethnic Conflicts and Political Development in Africa: The Challenge for the Church", BETFA Journal of the Ogbomosho Circle, $3,2004,52$. 
(God) in these religions indeed promotes division or violence, but religious actors have made it appear so. Religion is a powerful tool in the hands of those who use it. It is capable of performing dual purposes - uniting and dividing the society apart.

However, it is expedient to say that the dominant model of religious learning ordered by major Nigerian religions has been faith-oriented and overwhelmed by religious indoctrination and dogma. Religious education was used basically to get people to embrace Christianity or Islam. It could also serve as a process or formation for religious tolerance and dialogue. This has been jettisoned while the former has taken precedence over the latter. Consequently, most children and youths are educated within this structure and thus, inclined to a blind faith that is void of tolerance of the people of other faiths. Religious intolerance is thus, to a great extent, the outcome of the way in which religious education is taught.

Most times, the causes of the religious clashes/conflicts are, of course, a long history of small events, each of which, when it occurs, is carefully entered into the 'unforgiving and unforgettable memory' of the religious leaders as one more event that proves the crucial point that the government is in favour of one religion over the other. ${ }^{24}$ Pondering upon such past hurts in most cases, is like fanning the embers of violence and disintegrated society. The fall-out of such a situation is what Arinze from his own standpoint describes as what often degenerates into violence. In his view, some of the older religions have burdens of the past which their followers today inherit from history and for which the present followers are not responsible. Some of these historical memories are loaded with misunderstandings, exaggerations, unclarified historical details, unhealed anger handed down from generation to generation, unjustified generalization and a forcing of the mentality of current times to ages gone by. .25 Such as observed by Arinze is the religious atmosphere in Nigeria. This is because, most times religious leaders themselves who are expected to be seen as advocates of peace and love, are now the captain of division through their actions and unguarded utterances.

Religion is volatile in nature which often creates a reactionary effect and can easily attract massive support either in the positive or negative direction. This has brought to bear some of the cases of reactionary effects of religious unrest especially in the northern part of Nigeria, whereby there have always been some unwarranted religious confrontations among Christians and the Muslims in the region. Stating the obvious, some of these religious "fundamentalists" have been noticed to have laid claims to be fighting or carrying out their own religious allegiance to their "Brothers and Sisters" that are been persecuted in other parts of the world.

At times, religious leaders are found at the forefront of these confrontations by way of leading their followers to what they often term as "carrying out religious duties." A blood bath was said to have been averted through the timely intervention of some well-meaning people, including the President of United State of America - Barak Obama, where one Pastor Terry Jones almost succeeded in rabble-rousing his church members to embark on what may be termed as a sacrilegious mission in the public eye by burning of the Glorious Qur'an in the United State of America. ${ }^{26}$ Supposing he succeeded with such a destructive plan, the reactionary effects in Nigeria (especially in the northern part) and other parts of the world would have been likened to letting hell loose. This position can be buttressed with the experience that trailed the September 11 incident of 2001, which was given religious connotations. The Nigeria society witnessed religious confrontations (especially in the northern part of the country) and that led to wanton destruction of lives and property all in the bid to defend what some religious bigots perceived as the persecution of their "brothers and sisters" in other parts of the globe.

\section{Effects of Religious Incitements on Christian-Muslim Relations in Nigeria}

There is no doubt that religious leaders play very significant roles in determining the socio-political development and the stability of any nation. They are often seen as an epitome of "peace" and people look up to them as role models whose actions should be emulated in all ways. The consolidation tendency of Islam and that of expansionism of Christianity, in a multi-faith society as the case is in Nigeria have created a lot of unrests thus, resulting in stern confrontations among the religious adherents of both religions. The religious atmosphere in the past three decades will attest to this claim which has witnessed wanton destruction of lives and property.

Again, what one can see through this work is the fact that the religious leaders are unconsciously raising confronting armies (potential militants and fundamentalists) in silence through their unguarded utterances. This does not in any way help matters. Due to its volatile nature, many religious leaders (among Christians and Muslims) in Nigeria have succeeded in manipulating religion to press home their quest for "absolute truth", which their religion holds unto without putting into consideration the faith of others. Religious understanding and respect have therefore

${ }_{24}$ P.N. Emenalo, "The Relationship between Islam and Christianity in Nigeria: Problems and Prospects" a B.A. thesis submitted to the Department of Religious Studies, University of Jos, 1989, 104.

25 Francis C. Arinze, Meeting Other Believers, (Nairobi: Paulines Publications, 1997), 63.

26 William Branigin, “Obama Urges Florida Pastor to call off Koran Burning,” http://www.washingtononpost.com/wp-dyn/content/article/2010/09/09 Accessed March 16, 2012. 
become a mirage. Many adherents have become brainwashed and have been used as tools to foment trouble (political, religious or ethno-religious) in the nation.

The collusion of the two foreign religious worldviews (Christianity and Islam) in Nigeria has also brought about conflicts in conversion trends. It is revealing that the methods of proselytization used by religious leaders of these two religions appear to be a betrayal of the message of peace, love and spirituality they are canvassing for. Behind the evangelization and propagation of their religious truths lies real acrimony, bitterness, hostility, and even bloodshed at times which been waved like a dangerous dagger at the faces of people. The religious leaders see each other as "enemies" who must be conquered by all means, even if it requires going the extra mile of destroying the religious truths of other religions to win more converts. This tendency is silent and has been unconsciously bequeathed to the adherents of the two religions.

Furthermore, the methods of conversion used by religious leaders are sometimes crude and unspiritual for they might not give room for conviction and acceptance which in turn can lead to loyalty and devotion. According to the Islamic faith, "holy" war in most cases applied for the purpose of winning converts in the faith, and this is done through jihad. To the Christians, though they do not engage in physical combat or violence (especially in contemporary times unlike the days of the Crusaders in the $11^{\text {th }}$ Century) for the sake of winning souls and 'expanding the kingdom of God here on earth', but most of the Pentecostal preachers go all the way in discrediting other religions, making a mockery of them, thereby rubbishing their highly cherished religious beliefs and relegating them to the background. When a particular religious belief is been preached in such a manner, the resulting effect is usually disastrous. Under the guise of religion, those in the disadvantaged position often turn violent, believing they will enjoy divine favour. Worst still is the fact that the group that already enjoyed disproportionate power (and other resources) persuades themselves that religious injunctions, like the need to convert the "heathen" or the need to spread "freedom," justify the use of their "superior force" against disadvantaged others, construing such aggression as benevolent, meritorious, or holy. ${ }^{27}$

Through the unguarded utterances of some of the religious leaders, a platform for religious identity/affiliation which has replaced the corporate existence (communal living) of all in the society has been created. It is quite unfortunate that society has become polarized along religious lines. Thus, the explanation for the chronic and enduring malaise of any society or group cannot be considered outside of its operative social order or philosophy/principle underpinning it. The problem of religious intolerance therefore must be understood in the context of the operating religious order, and the philosophy/principle upon which it is based. Hence, the expression of love that does not cut across religious boundaries. The issue of intermarriage among adherents of the two religions today is a grave error, if not an abomination or completely a taboo. This is different in some cases and some ethnic groups like the Yoruba nation from the Southwestern part of Nigeria who could allow such, given some conditions. This simply means that, once one does not belong to a particular religious group, such a person might not be privileged to enjoy any benefit(s) coming from such a group. Akanmidu, in his own view on the above position of concept of love that does not cut across religious boundaries, posits on internal cleavages and its negative implication among the adherents of the two religions. According to him,

The process of internal cleavages endorses mutual proximity and builds religious interest and as well internally consumed as it becomes the source of segregation, resentment, strife and conflict across religious boundaries. This scenario has put in place primordial identities fanning mistrust (suspicious of trust) or distrust (absence of trust) ... the concomitant effect of this extraordinary development is significant to the overall resilient effect of the process of internal cleavages on religious truth claim. ${ }^{28}$

The disadvantages that accompany internal cleavages outweighed the advantages thereof. In most cases, it only promotes peaceful co-existence among members of the same religious group (intra benefit). However, considering Nigeria as a multi-religious society, such an ideology will not be relevant to its peaceful co-existence. It hampers the meaningful development of the nation at large.

On a deeper reflection, some of the incitements from religious leaders breed intolerance among the adherents of the two communities of faith - Christianity and Islam. Without mincing words, one will see that the religious adherents are highly intolerant to people of other religions. They become intolerant when the "religious faithful are unwilling to put up with the perceived lapses or excesses of others." ${ }^{29}$ To further establish this issue of intolerance, Yakubu Mohammed, Managing Editor of Newswatch Magazine, expressed a deeper concern where he was trying to understand the major problem between Christians and Muslims since they both preach peace. He copiously asked:

If the two religions preach peaceful co-existence, love and harmony, what went wrong in Kaduna State, where

\footnotetext{
Sunday Didam Audu, “A Historical Overview of the Violence of Religion and the 'Religiousness' of Violence," in Insight: Journal of Religious Studies, Babcock University, Vol.4, September, 2008, 102.

28 Rapheal Adebisi Akanmidu, "The Principles of Tolerance and Understanding: A Comparative Dimension of Coherence across Religious Boundaries in Nigeria," in M.J. Suleiman, and R.A. Akanmidu, (eds.), Religious Experiences in a Multi-Religious State, First National CONFAB, $18^{\text {th }}-22^{\text {nd }}$ October, 2010 , xxxiv.

29 Ehioghae, "Religion and Violence in Contemporary Nigerian Society," 354.
} 
so many lives were lost and inestimable property including such holy places like mosques and churches were desecrated and touched during the unprecedented display of intolerance and fanaticism? What went wrong? $?^{30}$

The position of Akanmidu as stated above concerning the evil of internal cleavages is sufficient enough to explain why the two religions that claim to preach love and peace still engage in a fierce battle of words and arms. Their concept of peace which the religious leaders often canvass for does not in any way cut across their religious boundaries. What went wrong actually was intolerance, misuse of religion, manipulation of religion by religious leaders and some unscrupulous individuals who often take advantage of disputes that could have been easily resolved for their selfish end. It is really disturbing that in one moment, perhaps for exhibitionism, the adherents of other religions are the best of friends, co-existing peacefully. Nevertheless, in another moment, their relations are soured by a deep-seated mutual distrust (absence of trust), mistrust (suspicion of trust), creating a wedge in human fellowship and love. In this case, their eyes are full of daggers and their hearts boil over with hatred, chauvinism, and in turn, bitterness takes over their relationships; and the floodgate of violence is thrown open which are evident in cases of religious violence.

There are combinations of factors that transcend the coast of religion which has helped in creating a "mass psychology of hatred" towards each other, thus, resulting in violence and possibly, reprisal attacks. These factors, which could be economical, political, social, or otherwise, and even religious as well, provide not only the rationale but also the justification for violent attacks, even if arson in principle is not approved by either of the religions. Consequently, religious confrontations which is often a consequence of the insensitivity on the part of religious leaders have resulted in the displacement of people, destruction of human beings and property which has in turn hampered the educational, political, social and psychological well-being of the nation. ${ }^{31}$

\section{Proposal for Meaningful Engagements}

Though Nigerians have reacted in different ways, and different suggestions have been made on the ambivalence roles of religious leaders in Christian-Muslim relations in Nigeria, it appears as though government and even the general public have turned deaf ears to the matter. Nevertheless, this work proposes workable solutions to the same matter in order to chart a course towards the desired pursuit - peaceful co-existence and national integration among the adherents of the two foreign religions in the Nigerian society.

To start with, the Fundamental Human Right of an individual should be sufficiently protected by the Government as contained in the Constitution of the Federal Republic of Nigeria, Sections 33 - 43, which include but not limited to the right to life, the dignity of human persons, personal liberty, fair hearing, private and family life, freedom of thought, conscience and religion, freedom of expression, among others. ${ }^{32}$ It is expressly stated that security of lives and property should be the primary assignment of governments. ${ }^{33}$ Religious intolerance, bigotry, fundamentalism and fanatism on the part of religious adherents of both religions have crippled the rights of many Nigerians. When the rights of an individual are fully guaranteed through the constitution of the country, whipping up of sentiments or instigating others by some religious leaders through their unguarded utterances will be reduced, if not completely eradicated. This is because the Rule of Law must surely take its full course.

Religious leaders should come to terms with this bitter truth that, there are other religious beliefs other than theirs and such should be respected and accommodated with the spirit of love and respect. They should ensure that preaching engagements are not inciting and or insulting. They should realize the fact that, making converts must be done through "persuasion" rather than "compulsion" or "alienation." Judging from both the Christian and Islamic points of view, it is obvious that a call to religion or salvation as the case may be is not expected to be by force or compulsion. It is meant to be an optional decision based on conviction. In Q.2:256, a believer is indeed expected to enjoy religious freedom and conscience. It therefore suggests that, religious adherents must not foist their religion on others because religion should be embraced on personal conviction, and not by compulsion. Also, in John 3:16, it is clear that, the word "whoever" in the call for salvation as contained in the verse of the Bible suggests an open invitation and not of compulsion or something to be imposed on anyone. Religious organizations should be allowed a full charge in controlling open-air preaching engagements, and effective monitoring measures should be put in place both by the government and the religious institutions like the Christian Association of Nigeria (CAN) and Ja'amtul Nasril Islam (JNI). This will help to checkmate any excesses and unguarded utterances which are capable of breeding religious intolerance and bigotry. It is therefore important to say that, religious virtues and the positive elements of all faiths like love, justice, compassion, forgiveness, patience among others should be the major focus and quest of the religious

\footnotetext{
30 Julius O. Adekunle, "Religion and Politics in Transition," in J.O. Adekunle, (ed.) Religion in Politics: Secularism and National Integration in Modern Nigeria, (Eritrea: Africa World Press, Inc., 2009), 10.

31 Celestina.O. Isiramen, "Religious Crises and Development in Nigeria," in C.O. Isiramen, et.al. (eds.) Religion and the Nigerian Nation: Some Topical Issues, (Ibadan: En-Joy Press \& Books, 2010), 338.

32 The 1999 Constitution of the Federal Republic of Nigeria, as amended in 2011, Sections $33-43$.

33 The 1999 Constitution of the Federal Republic of Nigeria, as amended in 2011, Section 14.
} 
leaders who serve as role models to many followers. In this wise, the internal mechanism should be developed by these religious bodies to handle any erring member(s) or religious leaders.

Nigeria as a nation has suffered so many setbacks due to incessant religious crises. One will be right to say that, the Nation has lost count of the number of lives that have been wasted in some of these religious confrontations, not to talk of the emotional and psychological trauma that many have suffered. The inability to accommodate others frequently results in the taking of arms against each other on the slightest disagreement even if by principle, arson is not allowed within such religious settings. It is on this basis that proper training should be given to religious leaders which should centre on religious tolerance, the sanctity of life and the universal brotherhood of man. Due to their influence on their followers, it has been argued that religious leaders can easily give directives which would be unquestionably responded to by their followers. Since it is "incumbent upon religious leaders - not only us but our people across the country to say, 'don't go there", ${ }^{34}$ then, such religious leaders should also be monitored in order for them not to abuse the privileged and overwhelming influence they have on their followers.

To effectively mitigate against the persistent occurrence of religious violence in Nigeria, government at all levels needs to be pro-active by way of promoting the culture of respect among adherents of different faiths. This can be better achieved through quality education and enlightenment of the people through mass media, civil society organizations and educational institutions; to respect and tolerate other religious views as well as extol the culture of others. Adherents of both religions should also be enlightened through the use of credible religious leaders, scholars, organizations, to imbibe the habit of reporting through the right channel, if offended by any member or group of the opposing religion instead of taking the law into their hands. It has been suggested that religion is best protected by promoting tolerance and non-discrimination and the cultivation of suitable attitudes of the people through education and sustained public enlightenment. ${ }^{35}$

It is true that "a hungry man is an angry man." Also, "an idle mind is the devil's workshop." There are two major "evils" that are confronting many Nigerian youths today - "unemployment" and "poverty". The government should put in place proper measures and workable structures to tackle these nagging problems which are the basic needs of everyone in society. Another issue that requires urgent attention to solving the problem of religious confrontations in Nigeria is illiteracy. Basic education should be provided for everyone under the Universal Basic Education programme. In line with this proposal, effective monitoring teams should also be put in place to monitor the implementation processes, so as to avoid the diversion of such plans into fulfilling a selfish end.

Religion as a phenomenon which in many times has become highly volatile and has assumed dangerous dimensions which often threatens national unity and stability. It therefore becomes imperative for educational awareness to be created right from the family and the religious institutional levels. At these levels, religious respect should be encouraged especially in a multi-religious society like Nigeria. The educational curricula should be reviewed from the lowest cadre of education to include subjects/courses like morality, ethics, religious interaction, the universal brotherhood of man, universal fatherhood of God, among others. Once the proper orientation of an individual is gotten from the grassroots, it will go a long way in enhancing the public life of the nation at large. In realizing this, the first chapter of The Great Learning (one of the Four Books of Confucius) succinctly thus presents these facts;

When true knowledge is achieved, then the will becomes sincere; when the will is sincere, then the heart is set right...; when the heart is set right, then the personal life is cultivated; when the personal life is cultivated, then the family life is regulated; when the family life is regulated, then the national life is orderly; and when the national life is orderly, then there is peace in the world... ${ }^{36}$

It is therefore imperative to submit here that, if proper education is not gotten at the individual level, people can easily be tossed anyhow by any form of religious indoctrinations that come their way. The determinant factor of the nature of the relationship that exists between Christians and Muslims is largely hinged on the nature of religious orientation given by religious leaders and also at the family level.

Dialogue is another veritable tool in resolving conflict. Dialogue here must be based on sincerity on the part of the interlocutors. There should be a display of sympathy and empathy, respect, the openness of mind, and also the quest to achieve peaceful co-existence no matter what the situation might be. It should also be noted that violence begets violence. To achieve a proper religious understanding among the adherents of the differing faiths, religious leaders should constantly and sincerely engage themselves in effective dialogue that is borne out of the genuine desire of all to promote peaceful co-existence between Christians and Muslims in Nigeria. This will enable them to fully

\footnotetext{
34 Libby Cathey, "Weaponizing Religion: Trump's attacks on Biden's Faith, Calling him 'against God”, ABC News, 12 August, 2020.

https://abcnews.go.com/Politics/weaponizing-religion-trumps-attacks-bidens-faith-calling-god/story?id=72240325 Accessed on 13 August, 2020.

35 Jerome Dalong Gamaliel, “An Analysis of Religion under the 1999 Constitution and Prospects for Peacebuilding in Nigeria," in S.G. Best, (ed.) Religion and Post Conflict Peacebuilding in Northern Nigeria, (Ibadan: John Archers (Publishers) Ltd., 2011), 137.

36 Innocent O. Umejesi, Oriental Religions: A Quest for Liberation and Wisdom, (Ekpoma: Pon Publishers Ltd., 2010$), 155$.
} 
appreciate other religious beliefs and practices. Part of the resolutions arrived at in the $30^{\text {th }}$ Anniversary of the Institute for Interreligious Affairs, Nigeria, which all saw as a reliable way of handling the problem of religious intolerance among people of diverse faiths is quite germane here. According to the leaders; "one of the practical orientations suggested is the dialogue of life, the most essential aspect of dialogue, wherein the daily practice of living together in brotherhood, helpfulness, and open-heartedness, Muslims and Christians mutually witness to each other from the values found in their own faiths." ${ }^{\text {37 }}$ It has been suggested that each participant must come to dialogue with honesty and sincerity, self-definition, avoidance of hard and fast assumptions, cautious, such a person must not be self-opinionated, reverence must be there, unlearn misinformation, etc. ${ }^{38}$ Therefore, every act of religious polemics must be frowned at with all honesty.

Functional security operative system should be put in place by the government. This will help in forestalling a situation whereby anyone could be tempted to take the law into their hands on the ground of any slightest disagreement, provocation, incitement, or wanting to flout the law of the land under the guise of religion. This behoves upon the government an urgent need to consider the issue of functional security with every sense of seriousness especially in the light of the position of Section 14 of the Constitution of the Federal Republic of Nigeria which states, in part that; "security and welfare of the people shall be the primary purpose of Government" 39 .

Going by the Nigerian National Anthem, two phrases read thus; "the labours of our Heroes past", and "shall never be in vain". If Nigerians must not destroy what the founding fathers built through their selfless services and commitments, then all hands must be on deck, (including the religious leaders) to jointly prevent or avert any form of religiously motivated attacks, and evil tendencies in the society. This should be seen as a demonstration of one's commitment, loyalty and patriotism to the common values of compassion, mercy, and social justice for all people. It is to this end, that there is a need to reiterate that the essential virtue of religions - love, peace, justice, the sanctity of life, among others should be emphasized upon. For any meaningful development and peaceful co-existence to be achieved in Nigeria today, as argued by Akinwumi, the people in government or the leaders that have taken over from the colonial masters now must explore this opportunity for meaningful development instead of squandering them and they must come out of their wrong interpretation of the state as an "arena for primitive accumulation of capital."

\section{CONCLUSION}

The discussion so far has centred on the ambivalence roles of religious leaders on Christian-Muslim relations in Nigeria. It has observed that in many cases, these religious leaders have either directly or indirectly become agents of tension and disunity through their unguarded utterances and actions, thus, leading to some state of mutual mistrust, distrust and suspicion among adherents of these religions. Again, it was also observed that the recourse to absolute truth as the pivot of religious tradition has been the womb that conceives religious intolerance, bigotry and violence. "Truthclaim, which is common with monotheistic religions, has led to conflicting nature of truth". ${ }^{41}$ It is quite unfortunate today that Nigeria has become a victim of religious intolerance with its attendant violent religious confrontations with innumerable numbers of lives wasted and invaluable property destroyed over the space of three decades. In most cases, the unguarded utterances and or publications of religious leaders cannot be divorced from the factors that are responsible for such incessant religious unrests in today's contemporary society.

To this end therefore, the principles of religious respect and understanding among Christians and Muslims are essential in enhancing the possibility of the "project Nigeria" and promoting religious understanding in a multi-religious society like Nigeria. It can therefore be submitted here with the words of Sa'adatu that:

Admittedly, conflicts and strife are inevitable, especially between different ideologies or religions, as indicated by the Crusades, which were religious wars in the Eleventh Century. However, it is the escalation of crises and conflicts, resulting in death and destruction, which is shocking and constitute a colossal threat to peace. Peace needs to be understood and practiced not only within the context of a cessation of hostilities, but by deeply identifying the underlying causes of the conflicts and finding solutions or preventive measures. Crises, conflicts and violence undermine national integration and peaceful co-existence among people of different faiths. ${ }^{42}$

Friction in every human society is a normal and common phenomenon which must be handled with care.

\footnotetext{
37 FABC Office of Ecumenical \& Interreligious Affairs (OEIA), FABC, Paper S.NO. 131, Dialogue in Asia $30^{\text {Th }}$ Anniversary First Bishops' Institute for Interreligious Affairs - (BIRA), 2012.

38 Benson Ohihon Igboin, “The Concomitance of Religious Conflicts in Nigeria: Secularity, Tolerance and Dialogue," in A.K.A. Chepkwony, and P.M.J Hess, (eds.) Human Views on God: Variety Not Monotony, (Essay in Honour of Ade P. Dopamu). Eldoret: Moi University Press, 2010$), 145$.

39 The 1999 Constitution of the Federal Republic of Nigeria, as amended in 2011, Section 14 (2b).

40 Olayemi Akinwumi, "Before We Set the House Ablaze: Let us Consult our Oracle (History)". The Third Inaugural Lecture Held at Nasarawa State University, Keffi on December $11^{\text {th }}, 2009,11$.

41 Igboin, "The Concomitance of Religious Conflicts in Nigeria: Secularity, Tolerance and Dialogue," 145.

42 Sa'adatu H. Liman, "Shari'a and Politics: Crises, Conflicts and Resolutions," in J.O. Adekunle, (ed.) Religion in Politics: Secularism and National Integration in Modern Nigeria, (Eritrea: Africa World Press, Inc., 2009), 171.
} 
Religious leaders therefore should come to the understanding that the era of Crusaders and Jihad of arm struggle is gone. What is needed in contemporary Nigeria is not rancour and religious intolerance, but that the culture of respect should be embraced among the adherents of the two major religions in Nigeria - Christianity and Islam. Therefore, "the prophets (religious leaders) in Nigeria must see themselves more importantly as peacemakers. While he is a warrior against social and political ills, his goal must always be the peaceful co-existence of the entire citizenry" ${ }^{43}$ This is important and also serves as a guide because, "if we push our nation too far to the point of a crisis and we prove right the prophets of doom that this nation will scatter, when it does, who gains?" ${ }^{44}$ The express answer is that everyone will surely suffer for it.

The Authors and belief presuppose that religion can be utilized to forge better relationships between adherents of different faiths than to be manipulated by a few elites, charlatans, and religious warlords/leaders, in order to divide, subjugate and oppress people with the main aim of pursuing selfish agenda as against the corporate existence of the nation. Therefore, "to keep Nigeria as one and indivisible nation is a task that must be earnestly pursued." Hence, religious leaders must see this as a "must to do" task which should be pursued with vigour and sincerity.

\section{ABOUT AUTHOR}

Rapheal Ojo Joseph (M.A), is a PhD candidate and a Lecturer, with the Department of Religion and African Culture, Adekunle Ajasin University, Akungba-Akoko, Ondo State, Nigeria.

\section{BIBLIOGRAPHY}

Adekunle, J.O. "Religion and Politics in Transition," in J.O. Adekunle, ed. Religion in Politics: Secularism and National Integration in Modern Nigeria, Eritrea: Africa World Press, Inc., 2009.

Akanmidu, R.A. "The Principles of Tolerance and Understanding: A Comparative Dimension of Coherence across Religious Boundaries in Nigeria," in Suleiman, M.J. and Akanmidu, R.A. eds., Religious Experiences in a Multi-Religious State, First National CONFAB, $18^{\text {th }}-22^{\text {nd }}$ October, 2010.

Akinseye, F.A. "Religion and Violence: A Christian Discourse," in R.A. Akanmidu, ed. et. al. Religion and Democracy in the $21^{\text {st }}$ Century, National Association for the Study of Religions - NASR., 2010.

Akinwumi, O. "Before We Set the House Ablaze: Let us Consult our Oracle (History)". The Third Inaugural Lecture Held at Nasarawa State University, Keffi on December 11 $1^{\text {th }}, 2009$.

Alli, Y. and Omokhunu, G. "Nigeria's Break-Up will be in Nobody's Interest, Onaiyekan Warns-Oritsejafor to Jonathan: Expose Sponsors of Boko Haram", in The Nation, Friday, May 31, 2013.

Arinze, F.C. Meeting Other Believers, Nairobi: Paulines Publications, 1997.

Audu, S.D. "A Historical Overview of the Violence of Religion and the 'Religiousness' of Violence," in Insight: Journal of Religious Studies, Babcock University, Vol.4, September, 2008.

Best, S.G. ed. Religion and Post-Conflict Peacebuilding in Northern Nigeria, Ibadan: John Archers Publishers Ltd., 2005.

Boer, J.H. Studies in Christian-Muslim Relations - Vol.2, Muslims: Why the Violence? In Nigeria's Decades of Blood, 1980-2002, Vol.2, Jos: Honey City Press, 2004.

Branigin, W. “Obama Urges Florida Pastor to call off Koran Burning,” Accessed March 16, 2012. http://www.washingtononpost.com/wp-dyn/content/article/2010/09/09

Cathey, Libby “Weaponizing Religion: Trump's attacks on Biden's Faith, Calling his 'against God”", ABC News, 12 August, 2020.

Deedat, A. Crucifixion or Cruci-Fiction? New York: Golden Empire Publications, 2011.

Ehioghae, E.M. "Religion and Violence in Contemporary Nigerian Society: A Proposal for Peaceful Co-Existence," in Akanmidu, R.A. ed. Thoughts in the Humanity. Ilorin: Decency Printers \& Stationary Ltd., 2011.

Ejenobo, D.T. "Religious Leaders as Political Actors: The Example of Israelite Prophets," in Abubakre, R.D. et.al. eds. Religion and Politics in Nigeria, Nigerian Association for the Study of Religions - NASR, 1993.

Emenalo, P.N. "The Relationship between Islam and Christianity in Nigeria: Problems and Prospects" a B.A. thesis submitted to the Department of Religious Studies, University of Jos, 1989.

FABC Office of Ecumenical \& Interreligious Affairs - OEIA, FABC, Paper S.NO. 131, Dialogue in Asia $30^{\text {Th }}$ Anniversary First Bishops'Institute for Interreligious Affairs BIRA, 2012.

Gamaliel, J.D. "An Analysis of Religion under the 1999 Constitution and Prospects for Peacebuilding in Nigeria,"

\footnotetext{
43 David T. Ejenobo, "Religious Leaders as Political Actors: The Example of Israelite Prophets," in Abubakre, R.D. et.al. (eds.) Religion and Politics in Nigeria, Nigerian Association for the Study of Religions (NASR), 1993, 30.

44 Y. Alli, and Godspower Omokhunu, "Nigeria's Break-Up will be in Nobody's Interest, Onaiyekan Warns - Oritsejafor to Jonathan: Expose Sponsors of Boko Haram", in The Nation, Friday, May 31, 2013, 59.
} 
in S.G. Best, ed. Religion and Post Conflict Peacebuilding in Northern Nigeria. Ibadan: John Archers Publishers Ltd., 2011.

Gwamna, J.D. "Ethnic Conflicts and Political Development in Africa: The Challenge for the Church", BETFA Journal of the Ogbomosho Circle, 3, 2004.

Gwamna, J.D. Religion and Politics in Nigeria, Bukuru: ACTS Bookshop, 2010.

Holborn, H. and Haralambos, M. Sociology: Themes and Perspectives, $7^{\text {th }}$ Edition, London: Harper Collins Publishers Limited, 2008.

Hornby, A.S. Oxford Advanced Learner's Dictionary of Current English, Eight Edition, Oxford New York: Oxford University Press, 2010.

Igboin, B.O. "The Concomitance of Religious Conflicts in Nigeria: Secularity, Tolerance and Dialogue," in Chepkwony, A.K.A. and Hess, P.M.J eds. Human Views on God: Variety Not Monotony, Essay in Honour of Ade P. Dopamu. Eldoret: Moi University Press, 2010.

Isiramen, C.O. "Religious Crises and Development in Nigeria," in C.O. Isiramen, et.al. (eds.) Religion and the Nigerian Nation: Some Topical Issues, Ibadan: En-Joy Press \& Books, 2010.

Liman, S.H. "Shari'a and Politics: Crises, Conflicts and Resolutions," in Adekunle, J.O.ed. Religion in Politics:

Secularism and National Integration in Modern Nigeria, Eritrea: Africa World Press, Inc., 2009.

Lindt, G. "Leadership", in Encyclopaedia of Religion, Vol.8. 2 $2^{\text {nd }}$ edition, Jones, Lindsay ed. Detroit: Thomas Gale, 2005.

Molloy, M. Experiencing the World's Religions, London: Mayfield, 2002.

Moshay, G.J.O. Anatomy of the Qur'an, Ontario: Chick Publications, 2007.

Moshay, G.J.O. Who is this Allah? Ontario: Chick Publications, 2010.

Ojo, J.O. "Exegetical Study of Joshua 1:5-9 and the Need for Credible Leadership in African Christianity", in Fatokun, S.A. et al, eds. African Christianity in Local and Global Context, Ibadan: Department of Religious Studies, University of Ibadan, 2019.

Omoregbe, J.I. Comparative Religion: Christianity and other World Religions in Dialogue, Lagos: JOJA Press Ltd, 1999.

Omotosho, A.O. "Religious Violence in Nigeria - the Causes and Solutions: An Islamic Perspective," in Swedish Missiological Theme, 2003.

Onaiyekan, J.O. "Dividend of Religion in Nigeria", Being a Public Lecture Delivered at the University of Ilorin, Ilorin on $12^{\text {th }}$ May, 2010.

The 1999 Constitution of the Federal Republic of Nigeria, as amended in 2011.

Ukpe, J.I.J. and Tsendzuul, T.G. "Leadership and the Challenge of Development in Nigeria", Religions: Journal of the Nigerian Association for the Study of Religions, Vol.28,1, January, 2018.

Umejesi, I.O. Oriental Religions: A Quest for Liberation and Wisdom, Ekpoma: Pon Publishers Ltd, 2010.

"Religious leaders in Nigeria call for Peace and Interreligious Cooperation." Accessed February 20th, 2012. http://www.parliamentofreligions.org/index.cfm. 